\title{
RESEARCH NOTES НАУЧНЫЕ 3АMETКИ THE FIRST RECORD OF RHOGOGASTER CHAMBERSI (HYMENOPTERA, SYMPHYTA) FOR THE RUSSIAN FAUNA
}

\author{
Natalya A. Lengesova ${ }^{1, *}$, Veli Vikberg ${ }^{2}$, Alexander B. Ruchin ${ }^{3}$, Svetlana E. Mironova ${ }^{1}$ \\ ${ }^{1}$ Ulyanovsk State Pedagogical University, Russia \\ *e-mail: lengesova@yandex.ru \\ ${ }^{2}$ Liinalammintie 11 as. 6, Finland \\ e-mail:veli.vikberg@pp.inet.fi \\ ${ }^{3} J o i n t$ Directorate of the Mordovia State Nature Reserve and National Park «Smolny», Russia \\ e-mail: ruchin.alexander@gmail.com
}

Received: 01.04.2020. Revised: 18.04.2020. Accepted: 22.04.2020.

\begin{abstract}
During field studies conducted in 2014 and 2017, Rhogogaster (Cytisogaster) chambersi was found in the Mordovia State Nature Reserve (Republic of Mordovia, Russia). Data on this record are presented here. The studied species has been found for the first time in Russia. We present data of the Russian location and some information on the species distribution.
\end{abstract}

Key words: Mordovia State Nature Reserve, new locality, Republic of Mordovia, species, Tenthredinidae

\section{Introduction}

The Mordovia State Nature Reserve is located in the Temnikov district of the Republic of Mordovia. It belongs to the Central Russian subprovince of the Eastern European province of the broad-leaved forest region on the wooded right bank of the River Moksha. The forest-steppe naturally marks the boundary of the protected area from the south (Khapugin et al., 2016). The climate of the Mordovia State Nature Reserve is related to the Atlantic continental region of the temperate zone. Intensive entomological studies in recent years have shown many new and interesting features of Insecta species in the Mordovia State Nature Reserve area (Ruchin \& Artaev, 2016; Ruchin \& Lengesova, 2012; Ruchin \& Egorov, 2018; Tomaszewska et al., 2018).

The genus Rhogogaster Konow, 1884 (type species - Tenthredo viridis Linnaeus, 1758) is represented by a group of green sawflies, which are quite well isolated from the outwardly close genus of Tenthredo Linnaeus, 1758. Taeger et al. (2010) recorded 40 species of Rhogogaster s.l. worldwide, and placed seven of these in Rhogogaster s.str. and six in Cytisogaster. The remaining 27 species were left unplaced within the genus. In this report, the first results of sawfly fauna investigations are presented, including a new species for the Russian fauna.

\section{Results and Discussion}

Material. Russia: $1 \sigma^{\hat{-}}$ - Republic of Mordovia, Temnikov district, Mordovia State Nature Reserve, cor- don Polyansky $\left(54.7730^{\circ} \mathrm{N}, 43.4906^{\circ} \mathrm{E}\right), 18.05 .2014$, A.B. Ruchin; 19 - Republic of Mordovia, Temnikov district, Mordovia State Nature Reserve, quarter 357 $\left(54.7637^{\circ} \mathrm{N}, 43.1857^{\circ} \mathrm{E}\right), 04.07 .2017$, A.B. Ruchin.

Description. This species was presented by both males and females. Size: $6.0-8.5 \mathrm{~mm}$. The hind tibia are lined with black on the anterio-dorsal face. Most of the stigma is pale. Facial markings and saw teeth are diagnostic traits. The frontal area of the face with the surrounding ridge in front is pale, so, that the black facial patch is broken in front by the pale along the ridges. The colour of females is greenish white marked with black. The wings are with a stigma, mainly pale. The males differ in colour, so that the extent of black is less and all the pale flecks on the head and thorax are larger, although the pale front ridges of the frontal area may be obsolete, and the mesosternum is entirely pale. The eyes of the males are smaller and much further apart in front than the height of one, and the malar space about as long as the $2^{\text {nd }}$ antennal segment. The flight period is from May to July. It is associated with the plants Linum catharticum L. and L. usitatissimum L. (Benson, 1952; Liston, 2015; Taeger \& Viitasaari, 2015).

Distribution. The species is known from Austria, Belgium, Bulgaria, Croatia, France, Germany, Great Britain, Hungary, Italy, Moldova, the Netherlands, Slovakia, Switzerland (Benson, 1952; Roller et al., 2006; Savina et al., 2013; Taeger et al., 2018). In Russia this species has been discovered for the first time in the Republic of Mordovia. 


\section{Acknowledgements}

We thank Dr. Andreas Taeger (Senckenberg German Entomological Institute, Germany) for kindly agreeing to review the manuscript at an early stage.

\section{References}

Benson R.B. 1952. Hymenoptera, Symphyta. Handbooks for the Identification of British Insects. Vol. 6(2b). London: Royal Entomological Society. P. 51-137.

Khapugin A.A., Vargot E.V., Chugunov G.G. 2016. Vegetation recovery in fire-damaged forests: a case study at the southern boundary of the taiga zone. Forestry Studies 64(1): 39-50. DOI: 10.1515/fsmu-2016-0003

Liston A.D. 2015. New records and host plants of Symphyta (Hymenoptera) for Germany, Berlin and Brandenburg. Contributions to Entomology 65(2): 383-391.

Roller L., Beneš K., Blank S.M., Holuša J., Jansen E., Jänikke M., Kaluza S., Kehl A., Kehr I., Kraus M., Liston A.D., Nyman T., Nie H., Savina H., Taeger A., Wei M. 2006. Contribution to the knowledge of sawfly fauna (Hymenoptera, Symphyta) of the Low Tatras National Park in Central Slovakia. Naturae Tutela 10: 57-72.

Ruchin A.B., Artaev O.N. 2016. On expansion of the distribution range of some scoliid wasps (Scoliidae, Hymenoptera, Insecta) in the Middle Volga region. Research Journal of Pharmaceutical, Biological and Chemical Sciences 7(3): 2110-2115.

Ruchin A.B., Egorov L.V. 2018. Leptura aurulenta (Coleoptera, Cerambycidae), a new record of a very rare species in Russia. Nature Conservation Research 3(1): 88-91. DOI: $10.24189 /$ ncr.2018.003

Ruchin A.B., Lengesova N.A. 2012. Preliminary data on the sawfly fauna (Hymenoptera, Symphyta) in selected Protected Areas in the Republic of Mordovia. Proceedings of the Khvalynsky National Park 4: 31-38. [In Russian]

Savina H., Liston A., Boevé J.L., Heibo E., Heidemaa M., Jacobs H.J., Jansen E., Malm T., Mol A., Mol-Cramer T., Taeger A. 2013. The sawfly fauna of the Hautes-Pyrénées (France), with results of the 15th International Sawfly Workshop, 2011 (Hymenoptera, Symphyta). Bulletin de la Société entomologique de France 118(4): 443-462.

Taeger A., Blank S.M., Liston A.D. 2010. World Catalog of Symphyta (Hymenoptera). Zootaxa 2580(1): 1-1064. DOI: 10.11646/zootaxa.2580.1.1

Taeger A., Viitasaari M. 2015. European Rhogogaster s. str., with notes on several Asian species (Hymenoptera: Tenthredinidae). Zootaxa 4013(3): 369-398. DOI: 10.11646/zootaxa.4013.3.3

Taeger A., Liston A.D., Prous M., Groll E.K., Gehroldt T., Blank S.M. 2018. ECatSym - Electronic World Catalog of Symphyta (Insecta, Hymenoptera). Program version 5.0 (19 Dec 2018), data version 40 (23 Sep 2018). Müncheberg: Senckenberg Deutsches Entomologisches Institut (SDEI). Available from: https://sdei.de/ecatsym/ Tomaszewska W., Egorov L.V., Ruchin A.B., Vlasov D.V. 2018. First record of Clemmus troglodytes (Coleoptera: Coccinelloidea, Anamorphidae) for the fauna of Russia. Nature Conservation Research 3(3): 103-105. DOI: 10.24189/ncr.2018.016

\title{
ПЕРВАЯ НАХОДКА RHOGOGASTER CHAMBERSI (HYMENOPTERA, SYMРНYТА) ДЛЯ ФАУНЫ РОССИИ
}

\author{
Н. А. Ленгесова ${ }^{1}$, В. Викберг ${ }^{2}$, А. Б. Ручин ${ }^{3}$, С. Е. Миронова ${ }^{1}$ \\ ${ }^{1}$ Ульяновский государственный педагогический университет им. И.Н. Ульянова, Россия \\ e-mail:lengesova@yandex.ru \\ ${ }^{2}$ Лииналамминтие 11 ас. 6, Финляндия \\ e-mail:veli.vikberg@mail.htk.fi \\ ${ }^{3}$ Объединенная дирекция Мордовского государственного природного заповедника \\ имени П.Г. Смидовича и национального парка «Смольный», Россия \\ e-mail: ruchin.alexander@gmail.com
}

Во время полевых исследований в 2014 и 2017 гг. в Мордовском государственном заповеднике (Республика Мордовия, Россия) был обнаружен Rhogogaster (Cytisogaster) chambersi. В этой статье мы впервые сообщаем о данном виде для фауны России. Представлены данные о его находке в России и о природном ареале вида.

Ключевые слова: Tenthredinidae, вид, Мордовский государственный заповедник, новое местонахождение, Республика Мордовия 